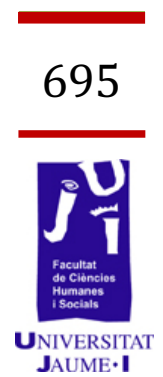

\title{
The Influence of Motivation in the Foreign Language Learning Process
}


Foreign Language Learning is currently becoming one of the most relevant issues to take into account in education. The globalisation process and its worldwide movement towards economy, finance, trade, immigration and communication among others, make inevitable to get into contact and communicate with people from different countries and cultures. This situation requires Foreign Language Learning skills, knowledge and motivation. Motivation plays an important role in the Foreign Language Learning process because it provides the first push to initiate a successful language learning process.

This project is focused on some motivational strategies to maximize students' language learning skills. The implementation of communicative, group and participative activities will help students to be motivated in the language classroom.

The article analyses a group of students belonging to an Intermediate Level Trade Course who were exposed to a teaching unit that combined both traditional methods (course book) and modern methods.

Firstly, I will introduce the current situation in secondary education and the role of motivation to achieve success in the Foreign Language classroom. Later, I will explain the practical application in an Intermediate Level Trade Course at a high school. I will also comment on the methodology and the activities carried out with the above mentioned group in order to enhance motivation. I will finally conclude about the effectiveness of creating a lesson plan and the use of relevant methodologies to enhance motivation in the Foreign Language classroom.

Key words: motivation, Foreign Language Learning, practical application, motivational strategies, methodology, success.

El aprendizaje de lenguas extranjeras se está convirtiendo hoy en día en uno de los temas más relevantes a tener en cuenta en la educación. El proceso de globalización y su movimiento mundial hacia la economía, las finanzas, el comercio, la inmigración y la comunicación, entre otros, hacen que sea inevitable entrar en contacto y comunicarse con personas de diferentes países y culturas. Para hacer frente a esta situación se requiere habilidades de aprendizaje de lenguas extranjeras, conocimiento de la misma y motivación. La motivación juega un papel fundamental en el proceso de aprendizaje de idiomas extranjeros ya que proporciona el primer empujón para iniciar un proceso de aprendizaje de idiomas con éxito.

Este proyecto se centra en algunas de las estrategias de motivación para maximizar las habilidades de aprendizaje de idiomas de los alumnos. La implementación de trabajo en grupo, de actividades interactivas y 
participativas y el uso del lenguaje verbal y comunicativo, ayudarán a los estudiantes a estar motivados en el aula de lengua extranjera.

El artículo analiza un grupo de estudiantes pertenecientes a un Curso de Comercio de Grado Medio que fueron expuestos a una unidad didáctica que combinaba métodos tradicionales como el uso del libro de texto con métodos modernos.

En primer lugar, haré una pequeña introducción sobre la situación actual en la educación secundaria y el papel de la motivación para lograr el éxito en la clase de lengua extranjera. Después, explicaré la aplicación práctica que se llevó a cabo en un curso de Comercio Intermedio en un instituto. También comentaré la metodología y las actividades llevadas realizadas con el grupo propiamente dicho con el fin de aumentar la motivación. Finalmente, concluiré acerca de la importancia y eficacia de tener una programación para seguir en el aula y el uso de metodologías pertinentes para mejorar la motivación en el aula de lengua extranjera.

Palabras clave: motivación, Aprendizaje de un Idioma Extranjero, estrategias de motivación, metodología, éxito.

\section{Introduction}

Learning a Foreign Language is probably nowadays one of the most relevant challenges for students. A lot of research has been carried out to discover which factors affect foreign language learning. Within these factors, the most relevant ones when learning a foreign language are: age, sex, culture, identity, learners' variables, and students' interests. Nevertheless, teachers' behaviour and methodology, syllabus design, informal interactions with the students, nature of the assignments or even classroom environment are factor that affect students' predisposition, eagerness or motivation to learn a Foreign Language.

Motivation plays an important role in Foreign Language learning success, and although it is not the main factor, in the classroom context it may lead students to achieve their goal or not. Lack of motivation leads to lack of effort and ultimately lack of success. Due to the great importance that motivation plays when learning a Foreign Language, I have considered the influence of motivation in language learning for this project.

Some months ago, I had the pleasure to work with an Intermediate Level Trade Course in a high school for some months, and while participating in the classroom as an observer first and as a teacher later, I noticed a great lack of motivation and some passiveness in the Foreign Language classroom when learning a language. For that reason, this project is focused on the motivation of a heterogeneous group (in terms of English proficiency) studying English as a Foreign Language in a high school and how students' motivation can improve the Foreign Language Learning process. 


\subsection{The concept of motivation}

Motivation is today the most complex and challenging issue for language teachers. The term 'motivation' is an abstract and hypothetical term that we use to explain why people, in this case students, think and behave as they do. According to Dörnyei (2001) motivation is the process whereby a certain amount of instigation force arises, initiates action, and persists, and it provides the learners the primary stimuli for initiating second language learning. In other words, motivation can be seen as a force that moves a person to initiate an action and to keep on until the goals are achieved. Our past actions, and particularly the way we interpret our past successes and failures determine our current and future behavior, and we will be more motivated to do something out of our own than something that we are forced to do. No one can deny that our personal likes or dislikes (attitudes) also play an important role in deciding what we will do or not. Without sufficient motivation, however, even the brightest learners are unlikely to persist long enough to attain any really useful language (Dörnyei, 2001).

Theorists and researchers of human motivation point out two types of motivation: intrinsic and extrinsic motivation. Intrinsic motivation refers to somebody internal desires to perform a particular task itself or from the sense of satisfaction in completing or even working on a task. On the other hand, extrinsic motivation refers to the external factors that lead an individual to perform something. It is related to rewards such as money or grades and these rewards provide satisfaction and pleasure that the task itself may not provide. However, intrinsic motivation does not mean that a person will not seek rewards. It just means that such external rewards are not enough to keep a person motivated.

Although both types of motivation are considered crucial factors for students' achievement in language learning, most researches show that intrinsically motivated students have been able to develop higher successes when learning a L2 than others extrinsically motivated, and without the inclusion of external rewards. Besides this, intrinsically motivated students have more advantages because there is evidence showing that intrinsic motivation can promote student learning and achievement better than extrinsic motivation.

\section{Objectives}

Students' motivation in Foreign Language Learning is affected by several factors such as sex, age, culture, personal interests, past actions, expectations, social or effective factors, environment, and so on. However, everybody knows that keeping our students motivated is not an easy task and, apart from these factors, teachers' behaviour, methodology, materials, the structure of the course or even the informal interactions 
between teacher-student also have a large effect on students' predisposition to learn a foreign language.

The aim of this paper is to find out to what extent various factors affect these students' motivation and performance in Foreign Language Learning as well as to deal with some motivational strategies to promote these students' motivation.

\section{Materials and Methodology}

The research was carried out with an Intermediate Level Trade Course of 20 students. It was a quiet and a reduce group and with a low degree of motivation towards a foreign language. Their level in the L2 was lower than the expected one and most of them were not able to overcome the minimum competences or goals included in the syllabus.

During my observation period I noticed that this group had a great lack of motivation towards Foreign Language (FL) Learning mainly due to the methodology and the materials used in the foreign classroom. Both the methodology and the materials were not the appropriate because the teacher tended to use only the text book and she avoided to make either use new technologies or prepare some extra material. Teachers cannot follow a traditional methodological approach only based on lectures or just following the book and it is very important to make the necessary changes when something does not work. Moreover, students' lack of motivation and total passiveness in the classroom with regard to the FL was mainly focused on their lack of interests in learning a FL because they were unable to see its usefulness and its connection with real life. About three or four students hardly ever attended to FL lessons, some others did not pay attention because they were not interested in the $\mathrm{FL}$ and the rest got bored.

For that reason, before starting to work with them and to ensure the success of my practical intervention I asked the official teacher for permission to work with this group and to create and to give the students a questionnaire to evaluate the students' motivation. With this questionnaire my intention was to know the students' worries and interests and their opinions about the Foreign Language lessons. There were two questionnaires: a first one about the students' initial opinions about the FL lessons and a second one with their final opinions after my participation in the classroom. The first questionnaire is shown below: 
Table 1. Students' motivation questionnaire (Q1)

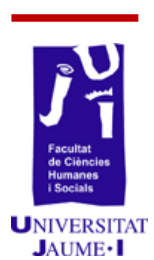

\section{Student's Motivation Questionnaire}

\begin{tabular}{|c|c|c|c|c|c|}
\hline & 1 & 2 & 3 & 4 & 5 \\
\hline $\begin{array}{l}\text { 1. Considero una pérdida de tiempo el hecho de tener que estudiar una lengua extranjera. } \\
\text { Debería ser optativo. }\end{array}$ & & & & & \\
\hline 2. Si hay algo que no entra en el examen no me esfuerzo por intentar entenderlo. & & & & & \\
\hline 3. Participaría más si los ejercicios fueran más dinámicos. & & & & & \\
\hline 4. Me conformo con aprobar, ¿ ¿para qué quiero sacar más nota? & & & & & \\
\hline 5. Cuando el profesor/a explica algo en clase y no lo entiendo, casi siempre le pregunto. & & & & & \\
\hline $\begin{array}{l}\text { 6. El profesor es creativo y presenta las actividades de manera atractiva e interactiva } \\
\text { combinando el libro de texto con otros materiales útiles. }\end{array}$ & & & & & \\
\hline 7. Si hiciéramos actividades en grupo y de manera oral aprenderíamos y participaríamos más. & & & & & \\
\hline 8. Me gusta que mis compañeros sepan que soy bueno/a en inglés. & & & & & \\
\hline $\begin{array}{l}\text { 9. Me gustan las lenguas extranjeras. Son importantes y me gustaría hablar inglés } \\
\text { perfectamente. }\end{array}$ & & & & & \\
\hline 10. Tengo claro cuál va a ser mi profesión en un futuro. & & & & & \\
\hline $\begin{array}{l}\text { 11. Cuando me pierdo en las explicaciones del profesor/a no me esfuerzo por intentar coger el } \\
\text { hilo otra vez, simplemente desconecto. }\end{array}$ & & & & & \\
\hline 12. Participo en las actividades planteadas en la clase de inglés. & & & & & \\
\hline $\begin{array}{l}\text { 13. Considero de gran importancia tanto el uso del libro de texto así como el uso de otros } \\
\text { materiales como herramienta útil de aprendizaje en el aula. }\end{array}$ & & & & & \\
\hline 14. El libro me aburre, quiero hacer actividades más dinámicas con mis compañeros. & & & & & \\
\hline 15. Participaría más si los ejercicios fueran más dinámicos. & & & & & \\
\hline $\begin{array}{l}\text { 16. Aprendería más y le encontraría más sentido a la clase de inglés si trabajáramos de manera } \\
\text { oral y con situaciones reales del día a día }\end{array}$ & & & & & \\
\hline $\begin{array}{l}\text { 17. Me siento motivado/a. Siento que en cada clase de inglés aprendo más y eso hace que mis } \\
\text { ganas por seguir aprendiendo aumenten. }\end{array}$ & & & & & \\
\hline
\end{tabular}


In this first questionnaire there were 17 items in which students were asked to show their agreement or disagreement with a five-point scale, ranging from totally agree to totally disagree (1 totally disagree, 2 disagree, 3 I don't mind, 4 agree, 5 totally agree). I included controversial and relevant items to deal with in this project. ${ }^{1}$

Here below you can see the second questionnaire (Q2) I gave them after my participation in the FL classroom:

Table 2. Students' opinions questionnaire (Q2)

\section{Questionnaire}

1. ¿Qué piensas de la metodología utilizada durante estas dos semanas? ¿de los materiales y actividades que se han llevado a cabo?

2. ¿Cómo prefieres trabajar, de manera individual o en grupo?

3. ¿Consideras que es positivo trabajar de manera colectiva con tus compañeros?

4. ¿Crees que has aprendido más trabajando principalmente en grupo y utilizando esta metodología? ¿por qué?

5. ¿Qué opinas de combinar el libro con otros materiales?

6. ¿Crees que el profesor es creativo y presenta las actividades de manera atractiva e interactiva combinando el libro de texto con otros materiales útiles?

7. ¿Prefieres trabajar de manera individual o de manera cooperativa y en grupo con tus compañeros? ¿Por qué?

8. ¿Consideras que el aprendizaje de un idioma extranjero, el inglés en este caso, debería ser opcional?

9. ¿Consideras de gran importancia tanto el uso del libro de texto así como el uso de otros materiales como herramienta útil de aprendizaje en el aula? ¿Por qué?

10. ¿Crees que en parte, tu falta de motivación para aprender inglés se debe a la actitud del profesor?

11. ¿Aprenderías más y si se trabajara de manera oral y con situaciones reales del día a día?

12. ¿Te sientes motivado? ¿Crees que en cada clase de inglés aprendes más? ¿Tus ganas por seguir aprendiendo aumentan cada día?

In this second survey, students were asked to answer some questions to verify whether some of the answers to the Q1 (Student's Motivation Questionnaire) were reliable or not. Here, they had to express with words how they felt during my practical intervention.

\subsection{Error problem solving}

Once the surveys were collected and having seen the results, I noticed that there was a great lack of motivation and interest so I started working in the creation of useful materials to cover these students' demands. Therefore, I focused on the most relevant aspects and worries I saw in the questionnaires, in such a way that I created dynamic, speaking and group work activities because my intention was to make lessons more attractive to them and above all to promote their intrinsic motivation in the $\mathrm{FL}$ Learning process.

\footnotetext{
${ }^{1}$ The items of the questionnaire are in Spanish because some of the students were unable to properly understand them in English so I translated them into their mother tongue.
} 


\section{Effective activities}

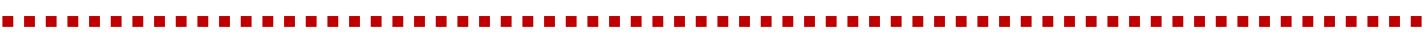

As I mentioned above, foreign language teachers cannot follow a traditional methodological approach only based on lectures or just following the book, but they would have to include varied activities or to make use of extra materials to meet the needs of all students. Besides, the importance of classroom climate and motivational tools is really important to maintain students motivated and keep their attention. To provide students with an interesting lesson, one possible strategy can be the creation of intrinsic motivation and the fact of working with unusual methodology can bring unexpected but positive outcomes because they will probably be more interested in the content of their lessons if they work in a different way.

For that reason, to cover all the students' demands, in the following paragraphs I state a series of successful strategies and methodological guidelines I implemented in the foreign classroom to deal with the motivation of these students. In order to implement interactive activities and taking into account the students' curriculum in the $\mathrm{FL}, \mathrm{I}$ decided to design a series of interactive activities where students had to put into practice their communicative skills, the digital competence and their capacity to work in a cooperative way.

In the following section I will show some relevant and effective activities I implemented. But first of all, I would like to explain that my classroom intervention was mainly focused on the vocabulary from the unit 7 (Evaluating products) in the course book Business Basics (2006), so most of the activities I will present below will be related with vocabulary. To implement interactive activities and taking into account that students had to know the vocabulary from unit 7 as part of the subject contents, I designed a series of both communicative and group work activities to make this task more attractive for them; playing role-plays, a Bingo, working with crosswords, doing listening, descriptions of products, etc.

\subsection{Group work}

Over the years, group work has become in an effective way where students can work together sharing their beliefs or opinions to fulfil a certain task or to achieve a certain learning goal.

From my point of view, group work is a good strategy to promote intrinsic motivation in the foreign language classroom because students not only have fun while working but they can also feel that they can freely communicate with each other without being assessed. Previous literature suggests that group work could arouse students' learning interests, cultivate their exploring ability and creative thinking and improve their team spirit and social communication skills (Fearon, McLaughlin, \& Eng, 2012; Olivera \& Strauss, 2004)

The first think I did to start working with this methodology was to create a pleasant and supportive atmosphere organising the classroom in the best way possible, moving all furniture to work more effectively. One of the activities I carried out was about describing products. I took about 
15 different objects to class and I put them into a box so anybody could not see the objects. Each group had to take an object from the box and after 4 minutes they had to describe it aloud to the other groups. The rest of the groups had to fill in the missing information about that product (colour, size, shape, use, length, material, price...) (See appendix 1).

Then, another group work activity I did in the foreign classroom was the invention of a product. Students had to focus on the invention of a new, interesting and useful product that did not exist in the real life. Apart from working in groups, they also had to cover speaking skills and creativity. The purpose with this activity was the contribution in the creation of the product in an active way.

The fact of implementing these two activities in the foreign language classroom was very positive and useful. They could see both activities from a business perspective where they took part in a company and they, as salesmen, had the challenge and the opportunity to present their product to another company. Moreover, with those activities, students not only worked on the vocabulary from the unit but also on creativity, sentence construction, communicative skills and cooperation.

Students were able to develop higher levels of thinking and reasoning and they had better attitudes towards the FL when they worked together because they felt equal among themselves. They felt much more confident when expressing their opinions about a certain activity and they were much more willing to receive feedback from their classmates.

These activities evidence the effectiveness of working in a cooperative and communicative way. Group work can promote not only students' motivation but also academic achievement in the foreign language.

\subsection{Communicative activities}

The choice of working with communicative activities carried out during my intervention was due, first of all, because of the students' demands and although oral teaching is nowadays one of the most problematic challenges for language teachers to face, it can have a lot of benefits and usefulness when learning a FL.

It was essential for the students to be aware of the importance of working in a communicative way because without any real purpose they felt reluctant to use oral language. For that, I created dynamic and interactive real life activities to encourage them to talk in English. Practicing dialogues and using real scenarios helped the students to see the usefulness of the foreign language. Apart from that, communicative activities also allowed them to practice with the new vocabulary from the unit, with grammar aspects and sentences in a real setting.

To carry out speaking activities, one of the activities I did was working with a role-play. Here, students worked in pairs, one was the customer (A) and the other one the seller (B) (See appendix 2). The customer had to ask for some characteristics of a particular product and the seller had to tell him/the characteristics of the product. They first had about 10 minutes to practice the role-play in their seats and afterwards they performed the role-play in front of the class, so I organised the classroom in such a way it 
seemed a real scenario (a store). Them they swapped roles so that both students could practice wh-questions.

My purpose was to encourage them to talk in English and practice speaking skills, and that was one of the most important benefits I got from this activity because they spoke in the foreign language all the time. They were also able to connect the activity with every day topics and it was a good strategy to promote their intrinsic motivation because they understood the essence and importance of the foreign language.

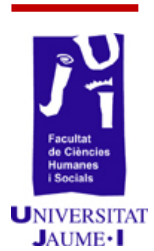

\section{Results}

The activities I planned to carry out with this group were prepared according to the students. Results obtained from Q1 can be seen in the following graph:

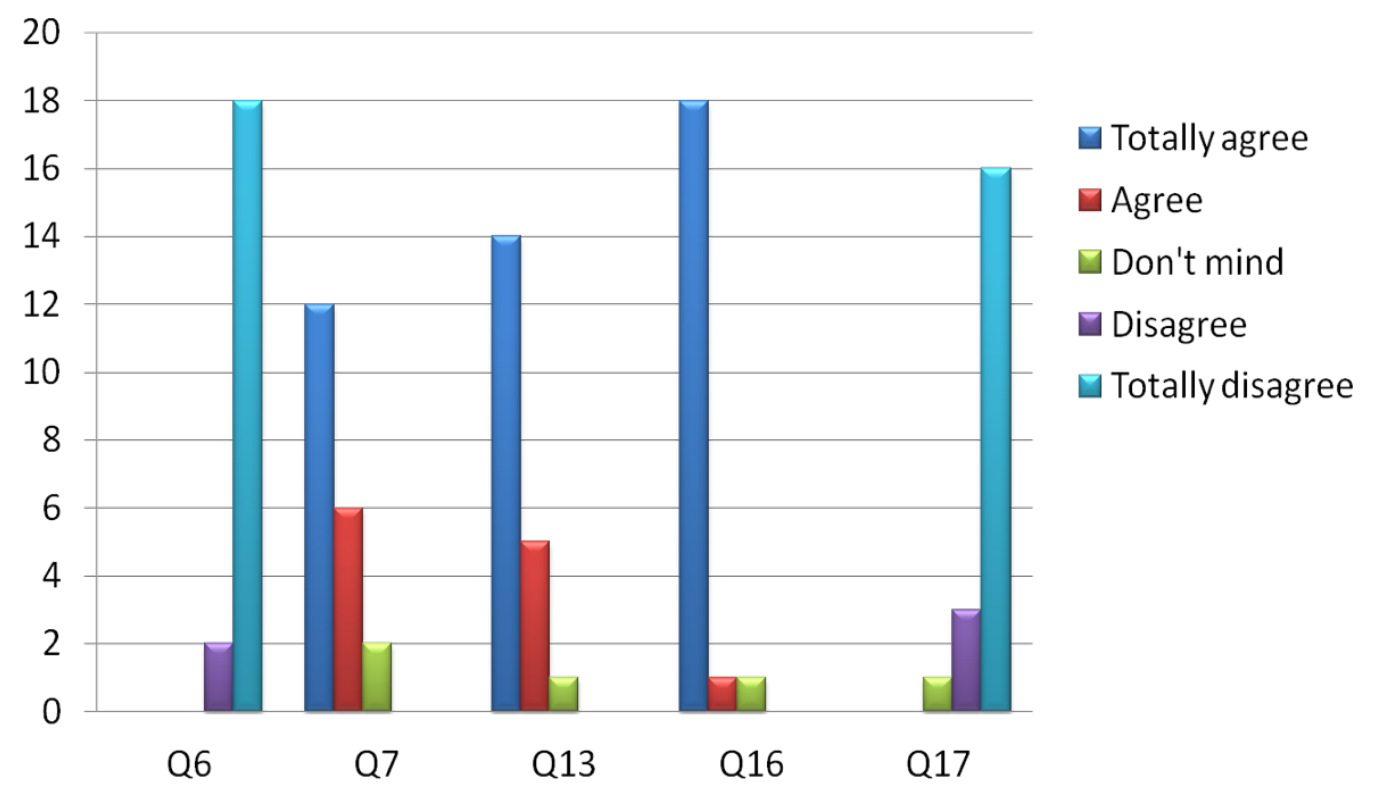

Figure 1. Results from the Students' Motivation Questionnaire (Q1)

The most relevant and controversial aspects are shown in the graph. It is worrying and shocking that almost all of the students think that they are not going to improve anymore. If students think like that it is because it is evident that there is a great lack of motivation and something has to be done to avoid this situation in the classroom. Below I show some of the students' comments taken from the Q1:

Q6: "El profesor es creativo y presenta las actividades de manera atractiva e interactiva combinando el libro de texto con otros materiales útiles". The results from this question number 6 show that any of the students totally agreed or agreed with the statement while 18 of them totally disagreed. So clearly, it would be much more useful to combine the course book with some dynamic activities. 
Q7: "Si hiciéramos actividades en grupo y de manera oral aprenderíamos y participaríamos más". The results show that most of the students totally agreed with this affirmation (12 students) and six of them agreed in the fact that working in groups would imply both predisposition to work in the foreign language and learning.

Q13: “Considero de gran importancia tanto el uso del libro de texto así como el uso de otros materiales como herramientas útiles de aprendizaje en el aula". Everybody thinks that it is very important to combine the course book with other materials when learning a foreign language. The course book can be an aid but it should not be the only material used in class and teachers should provide students with another extra and useful material to motivate them.

Q16: “Aprendería más y le encontraría más sentido a la clase de inglés si trabajáramos de manera oral y con situaciones reales del día a día". According to the results, 18 totally agreed in working communicative competence whereas nobody disagreed. Working with real materials in the foreign classroom could be very efficient because students are aware of the importance and the relation that the foreign language has. I personally also agree with the students because, what's the purpose of working only with grammar or vocabulary aspects in class? It is supposed that goal of learning a foreign language is to put it the in practise in the real world and it has no sense to learn isolated words or sentences by heart without any real purpose.

Q17: "Me siento motivado/a. Siento que en cada clase de inglés aprendo más y eso hace que mis ganas por seguir aprendiendo aumenten". Shockingly, any of them felt motivated in class so the great lack of motivation among all the students is clearly shown in the survey results.

Regarding the second questionnaire (Q2), I will comment in the following paragraph the results obtained (see Table 2). I am going to show you some relevant comments they wrote down after my participation in the classroom.

Student A: "Trabajar toda la hora con el libro de texto es un aburrimiento y el profesor debería darse cuenta de ello. Si se preparara un poco la clase y realmente quisiera enseñarnos de manera eficaz, intentaría buscar otros materiales y otras alternativa de enseñanza porque...... Me duermo en las clases..." (Q6)

Student B: "Prefiero trabajar mil veces más de manera cooperativa que de manera individual. Entiendo que hay actividades que se deben hacer de manera individual pero también pienso que se puede aprender mucho de tus compañeros cuando trabajas en grupo y de hecho yo he aprendido mucho de todos ellos. No tengo un nivel muy alto de inglés pero me han ayudado mucho y me he sentido muy arropada por todos ellos. ... He aprendido más este tiempo con esta metodología que en todo el curso. ... "(Q7) 
Student C: "Por supuesto. El libro de texto debería ser una ayuda y material de apoyo en clase pero no el único material utilizado. Hay muchos materiales útiles que se podrían utilizar y es importantísimo combinarlos todos." (Q13)

Student D: "El fin de cualquier tarea es ponerla luego en práctica en la vida real. No me sirve de nada aprenderme palabras o frases sueltas si luego no voy a ser capaz de ponerlas en práctica en la vida real"... Con los juegos de rol he aprendido mucho porque me he visto involucrado en una situación real, del día a día" (Q16)

Student E: "Estoy totalmente en desacuerdo. Siento que me he estancado y que ya no voy a aprender más. Necesito algo que me motive, otra metodología, otro tipo de actividades, no sé. Necesito que haya un cambio en clase porque mis ganas pro aprender son menos cada vez..." (Q17)

Student B says that group work methodology is useful because interaction and opinion sharing is possible among students. Besides, it is helpful because they learn the FL from others. Student D emphasizes the goal of learning a FL is to put it in practise in the real world. This student also says that it has no sense to learn isolated words or sentences by heart without any real purpose. Then, student $E$ is completely unmotivated in the FL classroom due to the methodology, materials and activities carried out by the foreign language teacher.

After the results obtained from the two surveys, I can assert that students who really wanted to learn the FL were able to master a reasonable working knowledge from the contents worked in the unit, and the others who were really unmotivated showed good language attitudes and predisposition to work in class.

Group work, speaking activities and the use of real and dynamic materials were really useful materials to keep the students motivated. The change in methodology also helped them to carry out their homework by combining traditional and new methods and, at the same time, it enhanced a communicative and a pleasant environment among the teacher and the students.

\section{Conclusion and discussion}

Although it seems easy to cope with motivational strategies, I would like to comment that not every strategy works in every context. Even those strategies which are generally the most reliable ones, may not work with a particular group or in particular situations. It is also possible that some strategies may work with one teacher or group better than with others, and they may even work better today than tomorrow. So, to carry out the most reliable strategies to motivate students, it is very important, first of all, to previously analyse the group you are going to work with (to know students' interests, worries, behaviours and needs) and then, plan the 
activities in such a way you make sure that these activities will catch students' attention.

Group work and speaking activities was an effective way to allow students freely engage in foreign language classroom discussions and they also were responsible to work quietly and respectfully. Moreover, I can conclude, after obtaining the results, that the study and the work I did with this group of students belonging to an Intermediate Level Trade Course had generally good results.

In conclusion, to promote motivation in the foreign language classroom, teachers should face with some motivational strategies. To carry out my classroom participation, the first thing I did was to take into account the students' attitudes and interests. Moreover, I had a good relationship with the students. I believe that having a good relationship with your students is also essential to keep them motivated. For that reason, during my teaching period I have always had a positive attitude and a positive relationship with the students, not only academically but also personally. Providing students with useful and real materials, dynamic tasks and suitable learning atmosphere are aspects that can be used to maximize students' motivation in the classroom.

\section{References}

Alonso TAPIA, J. (1991): Motivación y aprendizaje en el aula: cómo enseñar a pensar. Madrid: Santillana, DL 1994.

DöRnYEl, Z. (2001): Motivational strategies in the language classroom. Barcelona: UOC, 2005

DÖRNYEI, Z. (2005): The Psychology of the language learner: individual differences in second language acquisition. Mahwah, NJ. [etc.]: Lawrence Erlbaum, 2005

Grant, D \& McLARTY, R (2006): Business Basics - International. Student's Book: Updated for the international marketplace. Oxford: Oxford University Press, 1995.

Fearon, C., Mclaughlin, H., \& EnG, T. Y. (2012): Using student group work in higher education to emulate professional communities of practice. Education + Training Journal, 54(2/3), 114-125.

GonzÁlez Fernández, A. (2005): Motivación académica: teoría, aplicación y evaluación. Madrid: Pirámide, cop, 2005.

LogAn, Frank, A. (1976): Fundamentos de aprendizaje y motivación. México, DF: Trillas, 1976. 